\title{
EFEKTIVITAS PENGGUNAAN KOMIK BERBASIS SIKAP ILMIAH TERHADAP SIKAP PEDULI LINGKUNGAN MAHASISWA UNIVERSITAS SLAMET RIYADI
}

\author{
Anggit Grahito Wicaksono ${ }^{1}$, Ratna Widyaningrum ${ }^{2}$ \\ ${ }^{1}$ Fakultas Keguruan dan Ilmu Pendidikan, Universitas Slamet Riyadi \\ email: ${ }^{1}$ gara_hito@yahoo.co.id; ${ }^{2}$ ratnawidya133@gmail.com
}

\begin{abstract}
The purpose of this research is to know: (1) difference of environmental care attitude of students before and after using comic based scientific attitude on basic natural science subjects and (2) effectiveness of the use of comic based scientific attitudes toward environmental care attitude on basic natural science subjects. This research uses pre experimental quantitative research method with one group pretestposttest design with t-test and N-gain test analysis technique. The results of the first hypothesis test concluded that there are differences in environmental cares attitude before and after using comic based scientific attitude and experienced an increase in average values of environmental care attitude before and after using comic based scientific attitude. The result of the second hypothesis test concludes that the use of comic based scientific attitude is effective on the environmental cares attitude of students on the medium criterion with the value of the $N$-gain test of 0.425 .
\end{abstract}

Keywords: Comics, Scientific Attitude, Environmental Care Attitude

\section{PENDAHULUAN}

Program studi Pendidikan Guru Sekolah Dasar (PGSD) merupakan lembaga yang menyiapkan calon guru Sekolah Dasar. Lembaga mengharapkan lulusan yang dihasilkan tidak hanya memiliki pemahaman dan wawasan ilmu pengetahuan. Namun, lulusan yang dihasilkan juga harus terampil dan memiliki kompetensi paedagogik, profesional, kepribadian, dan sosial. Banyak mata kuliah yang diberikan dalam rangka pembentukan kompetensi lulusan tersebut. Salah satu mata kuliah yang diberikan adalah Ilmu Alamiah Dasar (IAD). IAD merupakan mata kuliah yang menjadi peletak dasar-dasar IPA sehingga mahasiswa memiliki wawasan yang matang tentang metode ilmiah dan ilmu pengetahuan secara umum. Salah satu materi dalam mata kuliah IAD adalah wawasan isu lingkungan baik lokal, nasional, maupun global. Indonesia merupakan negara yang kaya akan sumber daya alam. Potensi alam erat kaitannya dengan manajemen eksplorasi dan manajemen pemberdayaan lingkungan hidup. Ekplorasi sumber daya alam maupun mineral seharusnya diimbangi dengan menjaga kualitas lingkungan sekitar agar tetap terjaga seimbang (Mariyanah, 2005). Hal ini penting agar kejadian-kejadian berupa bencana alam maupun pencemaran lingkungan dapat diminimalisasi.

Hasil observasi yang telah dilakukan terhadap perilaku mahasiswa di Prodi Pendidikan Guru Sekola Dasar (PGSD) Fakultas Keguruan dan Ilmu Pendidikan (FKIP) Universitas Slamet Riyadi (UNISRI) dalam menjaga lingkungan baik secara lokal maupun nasional masih sangat rendah. Hal ini tampak pada perilaku mereka saat membuang sampah tidak pada tempatnya, padahal sudah tersedia tempat sampah yang memadai. Berdasarkan hasil wawancara dengan dosen pengampu mata kuliah IAD didapatkan fakta bahwa perkuliahan tentang wawasan isu 
lingkungan saat ini belum dapat memunculkan sikap peduli lingkungan mahasiswa. Hal ini terjadi karena keterbatasan dosen dalam penggunaan media pembelajaran dan hanya cenderung menyampaikan materi tersebut dengan ceramah saja. Media pembelajaran hanya slide presentasi, sehingga mahasiswa hanya memiliki catatan atau hand out dari slide presentasi dosen sebagai sumber belajar.

Menurut Arsyad (2011: 4), media pembelajaran adalah perantara yang membawa pesan atau informasi bertujuan instruksional atau mengandung maksudmaksud pengajaran antara sumber dan penerima. Menurut Tella (2007: 154), tanpa dukungan media pembelajaran, kegiatan belajar mengajar yang hanya menggunakan buku pelajaran sebagai satu-satunya sumber belajar oleh siswa, menjadikan suasana belajar menjadi kurang menarik dan membosankan serta membuat anak kurang mengembangkan kemampuan serta kreativitas siswa pada materi tersebut. Memotivasi siswa dipandang sebagai aspek penting dalam pembelajaran yang efektif (Bossard, 2005: 43). Ketika siswa kurang tertarik terhadap pelajaran maka akan mempengaruhi cara mereka bereaksi atau memperhatikan guru. Dari beberapa paparan tersebut dapat disimpulkan bahwa media pembelajaran merupakan peralatan yang membawa pesan-pesan untuk mencapai tujuan pembelajaran. Media pembelajaran yang inovatif dan populer di kalangan mahasiswa saat ini adalah media pembelajaran berupa komik.

Hal tersebut sejalan dengan pendapat Tatalovic (2009: 23) yang menyatakan bahwa, komik adalah bentuk seni yang populer terutama di kalangan remaja dan dengan demikian memberikan potensi untuk pendidikan sains dan komunikasi.

$$
\text { Sudjana dan Rivai (2009: 64) }
$$
memberikan definisi yang lebih komprehensif bahwa, komik adalah suatu bentuk kartun yang mengungkapkan karakter dan memerankan suatu cerita dalam urutan yang erat dihubungkan dengan gambar untuk memberikan hiburan kepada para pembacanya. Sementara menurut McCloud (2001: 20), komik adalah gambar-gambar atau lambang-lambang lain yang terjukstaposisi dalam urutan tertentu bertujuan untuk memberikan informasi dan/mencapai tanggapan estetis dari para pembacanya. Oleh karena itu, jika media yang menyenangkan ini dipakai dalam proses pembelajaran, akan membawa suasana menyenangkan dalam proses pembelajaran. Jika siswa mendapati suasana yang menyenangkan dalam proses pembelajaran, mereka akan terlibat total dalam proses pembelajaran itu. Keterlibatan secara total ini penting untuk melahirkan hasil akhir yang sukses.

Hasil belajar merupakan perubahan kecakapan fisik, mental, kecerdasan dari kegiatan belajar pada pendidikan formal maupun non formal, yang akan dimanfaatkan dalam kehidupan sehari-hari (Ariyanto 2016: 134). Hasil belajar Mata Kuliah IAD erat kaitannya dengan sikap ilmiah dan sikap peduli lingkungan. Menurut Muslich (2011: 34), sikap ilmiah merupakan sikap yang harus ada pada diri seorang ilmuwan atau akademisi ketika menghadapi persoalan-persoalan ilmiah.

Selain itu menurut Bossard, et. all. (2005: 45) sikap ilmiah juga diartikan sebagai suatu kecenderungan, kesiapan, kesediaan, seseorang untuk memberikan respon/tanggapan/tingkah laku secara ilmu pengetahuan dan memenuhi syarat (hukum) 
ilmu pengetahuan yang telah diakui kebenarannya. Artikel oleh Wicaksono dan Jumanto (2016: 212) menyatakan bahwa sikap ilmiah adalah suatu keadaan dalam diri individu yang disertai dengan perasaan dan alasan tertentu untuk memberikan respon/ tanggapan/ tingkah laku guna memperoleh suatu fakta berdasarkan ilmu pengetahuan.

Selain sikap ilmiah, mata kuliah IAD sangat terkait dengan sikap peduli lingkungan. Sikap peduli lingkungan merupakan sikap dan tindakan yang selalu berupaya mencegah kerusakan pada lingkungan alam di sekitarnya, dan mengembangkan upaya-upaya untuk memperbaiki kerusakan alam yang sudah terjadi (Mulyana, 2009: 24). Menurut Kemendiknas (2010: 10) sikap peduli lingkungan hidup adalah suatu sikap dan perilaku yang selalu berupaya mencegah kerusakan alam dan sekitarnya serta mengembangkan upaya-upaya untuk memperbaiki kerusakan alam yang telah terjadi.

Narwanti (2011: 30) berpendapat, sikap peduli lingkungan merupakan sikap dan tindakan yang berupaya mencegah kerusakan pada lingkungan alam di sekitarnya, dan mengembangkan upaya-upaya untuk memperbaiki kerusakan alam yang sudah terjadi. Berdasarkan uraian di atas dapat disimpulkan bahwa sikap peduli lingkungan berarti sikap yang diwujudkan dalam kehidupan sehari-hari untuk melestarikan, memperbaiki dan mencegah kerusakan dan pencemaran lingkungan.

Berdasarkan paparan di atas maka perlu adanya suatu penelitian menggunakan media pembelajaran yang kreatif, inovatif, dan menarik untuk mahasiswa sehingga dapat memberikan makna tentang sikap peduli lingkungan dalam perilaku mahasiswa. Media pembelajaran tersebut adalah media komik tentang perubahan iklim berbasis sikap ilmiah yang dapat menumbuhkan kesadaran dan kepedulian mahasiswa terhadap lingkungan. Penggunaan media komik tersebut diharapkan efektif dalam menumbuhkan kepeduliah mahasiswa terhadap lingkungan. Dengan demikian, penelitian ini bertujuan untuk mengetahui perbedaan sikap peduli lingkungan mahasiswa sebelum dan sesudah menggunakan komik berbasis sikap ilmiah pada mata kuliah Ilmu Alamiah Dasar dan mengetahui efektivitas penggunaan komik berbasis sikap ilmiah terhadap sikap peduli lingkungan mahasiswa pada mata kuliah Ilmu Alamiah Dasar.

\section{METODE PENELITIAN}

Metode yang digunakan dalam penelitian ini adalah metode penelitiaan kuantitatif pre experimental dengan desain penelitian one group pretest-posttest design. Populasi dalam penelitian ini adalah seluruh mahasiswa semester dua Program Studi PGSD FKIP UNISRI tahun akademik 2016/2017 yang berjumlah 95 mahasiswa kemudian dilakukan purposive sampling dihasilkan sampel berjumlah 32 mahasiswa. Teknik pengumpulan data yang digunakan dengan menggunakan angket, wawancara, dan observasi. Uji validitas data menggunakan validitas konstruk untuk instrumen angket sikap peduli lingkungan. Teknik analisis data yang digunakan untuk menguji hipotesis adalah uji t dan uji N-gain dengan bantuan SPSS 21.

\section{HASIL DAN PEMBAHASAN}

Hasil penelitian ini terdiri dari deskripsi data, uji prasyarat analisis dan pengujian hipotesis. Adapun deskripsi data penelitian ditunjukkan seperti pada tabel 1 . 
Tabel 1. Deskripsi Data Penelitian

\begin{tabular}{|c|c|c|c|c|}
\hline Variabel Penelitian & Mean & STD & Min & $\operatorname{Max}$ \\
\hline $\begin{array}{l}\text { Pretest Sikap Peduli } \\
\text { Lingkungan }\end{array}$ & 64,25 & 3,976 & 56 & 72 \\
\hline $\begin{array}{l}\text { Posttest Sikap Peduli } \\
\text { Lingkungan }\end{array}$ & 79,44 & 7,339 & 68 & 92 \\
\hline
\end{tabular}

Pada uji prasyarat analisis terdiri dari uji normalitas dan uji homogenitas. Berdasarkan hasil uji normalitas diperolah nilai signifikansi pretest sikap peduli lingkungan 0,200 > 0,05, maka Ho diterima sehingga pretest sikap peduli lingkungan berdistribusi normal. Posttest sikap peduli lingkungan memiliki signifikansi 0,200 >0,05 maka Ho diterima sehingga posttest sikap peduli lingkungan berdistribusi normal.

Berdasarkan hasil uji homogenitas diperoleh bahwa pretest sikap peduli lingkungan memiliki signifikansi 0,181>0,05 menunjukkan bahwa Ho diterima sehingga pretest sikap peduli lingkungan homogen. Posttest sikap peduli lingkungan memiliki signifikansi 0,094 > 0,05 menunjukkan bahwa Ho diterima sehingga posttest sikap peduli lingkungan homogen.

Pada pengujian Hipotesis 1 diperoleh hasil Paired Sample T-test pada tabel 2 sebagai berikut:

Tabel 2. Hasil Paired Sample T-test

\begin{tabular}{llll}
\hline & $\mathrm{t}$ & $\mathrm{df}$ & $\begin{array}{c}\text { Sig. (2- } \\
\text { tailed) }\end{array}$ \\
\hline Pair 1 & & & \\
Hasil Pretest & & & \\
$\begin{array}{l}\text { Sikap Peduli } \\
\text { Lingkungan - } \\
\text { Posttest Sikap } \\
\text { Peduli }\end{array}$ & -14.313 & 31 & 0.000 \\
Lingkungan & & & \\
\hline
\end{tabular}

Dari tabel 2 diperoleh nilai $\mathrm{t}$ sebesar 14,313 dengan sig. (2-tailed) sebesar 0,000 <
0,05 dan dari tabel 1 diperoleh rata-rata nilai sikap peduli lingkungan sebelum menggunakan komik sebesar 64,25 dan sesudah menggunakan komik sebesar 79,44. Dari hasil tersebut dapat disimpulkan bahwa ada perbedaan sikap peduli lingkungan mahasiswa sebelum dan sesudah menggunakan komik berbasis sikap ilmiah dan mengalami peningkatan nilai rata-rata sikap peduli lingkungan sebelum dan sesudah menggunakan komik berbasis sikap ilmiah.

Pegujian Hipotesis 2 menunjukkan bahwa perhitungan rumus $\mathrm{N}$-gain diperoleh hasil sebesar 0,425, jika nilai tersebut dikonsultasikan dengan tabel kriteria efektivitas pembelajaran artinya penggunaan komik berbasis sikap ilmiah efektif terhadap sikap peduli lingkungan mahasiswa dengan kriteria sedang.

Hasil penelitian ini menunjukkan bahwa ada perbedaan sikap peduli lingkungan mahasiswa sebelum dan sesudah menggunakan komik berbasis sikap ilmiah pada mata kuliah IAD. Hal tersebut ditunjukkan dengan rata-rata nilai sikap peduli lingkungan sebelum menggunakan komik sebesar 64,25 dan sesudah menggunakan komik sebesar 79,44. Perbedaan rata-rata nilai sikap peduli lingkungan menunjukkan bahwa penggunaan komik berbasis sikap ilmiah efektif dalam peningkatan sikap peduli lingkungan mahasiswa yang termasuk dalam kriteria sedang.

Penggunaan komik berbasis sikap ilmiah materi perubahan iklim adalah salah satu cara yang dapat memunculkan sikap peduli lingkungan mahasiswa yang dapat memahami kepedulian terhadap lingkungan dengan cara menyenangkan menggunakan komik berbasis sikap ilmiah dan berbagai implementasinya dalam kehidupan sehari-hari. Sikap peduli 
lingkungan adalah sikap yang harus dibentuk dan dikembangkan sejak dini. sikap peduli lingkungan berarti sikap yang diwujudkan dalam kehidupan sehari-hari untuk melestarikan, memperbaiki dan mencegah kerusakan dan pencemaran lingkungan. Komponen sikap peduli lingkungan adalah kerja keras untuk melindungi alam, menghargai kesehatan kebersihan, bijaksana dalam menggunakan Sumber Daya Alam (SDA), dan tanggung jawab terhadap lingkungan.

Hasil analisis data tersebut dapat terjadi karena materi tentang perubahan iklim dibuat lebih menarik perhatian dan bermakna bagi mahasiswa dengan disajikan dalam bentuk komik yang inovatif dengan cerita yang mewakili sikap ilmiah mahasiswa yang salah satunya adalah sikap peduli lingkungan. Sejalan dengan penelitian yang pernah dilakukan oleh Mulyani (2009: 32) yang menyatakan bahwa penggunaan media komik strip efektif untuk mencapai kompetensi. Hasil penelitian tersebut mengungkapkan bahwa penggunaan media berupa komik strip dapat meningkatkan antusiasme dan ketertarikan anak dalam pembelajaran sehingga kompetensi anak dapat meningkat dengan signifikan.

Penelitian lain dilakukan oleh Ikhsaniyah (2015: 69) yang membahas tentang efektivitas penggunaan media komik biologi terhadap motivasi dan hasil belajar kognitif menyimpulkan bahwa penggunaan media komik biologi efektif terhadap motivasi maupun hasil belajar kognitif. Penelitian- penelitian yang dilakukan menunjukkan bahwa media komik adalah salah satu media yang cukup efektif dalam peningkatan aspek kognitif dan aspek afektif dalam pembelajaran termasuk juga dalam peningkatan sikap peduli lingkungan.

\section{SIMPULAN DAN SARAN}

Berdasarkan hasil dan pembahasan maka kesimpulan pertama dalam penelitian ini adalah ada perbedaan sikap peduli lingkungan mahasiswa sebelum dan sesudah menggunakan komik berbasis sikap ilmiah pada mata kuliah Ilmu Alamiah Dasar Prodi PGSD Universitas Slamet Riyadi tahun akademik 2016/2017. Penggunaan komik berbasis sikap ilmiah efektif terhadap sikap peduli lingkungan mahasiswa mata kuliah Ilmu Alamiah Dasar Prodi PGSD Universitas Slamet Riyadi tahun akademik 2016/2017.

Hasil penelitian dapat menjadi pertimbangan peneliti lain untuk memasukkan isu-isu lingkungan lokal maupun nasional di sekitar mahasiswa dalam pembelajaran dan mengintegrasikan dengan fenomenafenomena dalam kehidupan sehari-hari sebagai wujud penanaman sikap peduli lingkungan. Selain itu perlunya selalu menjaga dan meningkatkan kualitas pembelajaran IAD yang bermuatan lingkungan dengan diintegrasikan dalam media pembelajaran inovatif karena penggunaan komik berbasis sikap ilmiah efektif terhadap sikap peduli lingkungan mahasiswa. 


\section{DAFTAR PUSTAKA}

Ariyanto, Metta. 2016. Peningkatan Hasil Belajar IPA Materi Kenampakan Rupa Bumi Menggunakan Model Scramble. Profesi Pendidikan Dasar. Vol. 3. No. 2, hlm. 133-14

Arsyad, Azhar. (2011). Media Pembelajaran. Jakarta: Rajawali Pers.

Bossard, D., Lewenstien, B., and Bonney, R. (2005). Scientific Knowledge and Attitude Change: The Impact of a Citizen Science Project. International Journal of Science Education, 27 (9), 1099-1121.

Ikhsaniyah, Wahdatul. (2015). Efektivitas Media Komik Biologi Materi Virus Melalui Pembelajaran Koopertif Tipe Cooperative Integrated Reading and Compositing (CIRC) terhadap Motivasi dan Hasil Belajar Biologi Siswa Kelas X SMA N 1 Sewon. Skripsi. UIN Sunan Kalijaga Yogyakarta.

Kemdiknas. (2010). Desain Induk Pendidikan Karakter. Jakarta: Badan Penelitian dan Pengembangan Pusat Kurikulum.

Mariyanah, Nur. (2005). Efektivitas Media Komik dengan Media Gambar dalam Pembelajaran Geografi Pokok Bahasan Perhubungan dan Pengangkutan”. (Studi Eksperimen Pada Siswa Kelas II SMP N I Pegandon Kabupaten Kendal). Skripsi. UNNES

McCLoud, Jr, G.S. (2001). Sistem Informasi. Yogyakarta: Andi Offset.

Mulyana, Rahmat. (2009). Penanaman Etika Lingkungan Melalui Sekolah Peduli dan Berbudaya Lingkungan. Jurnal Tabularasa PPS UNIMED. 6 (2), 175-180.

Mulyani, Tri. (2009). Efektivitas Penggunaan Media Komik Strip Pada Pembelajaran Materi Saling Ketergantungan Dalam Ekosistem di SMP Negeri 1 Kaliwungu Kudus. Skripsi. UNNES.

Muslich, Masnur. (2011). Pendidikan Karakter: Menjawab Tantangan Krisis Multidimensional. Jakarta: Bumi Aksara.

Narwanti, Sri. (2011). Pendidikan Karakter Pengintegrasian 18 Nilai Peembentuk Karakter dalam Mata Pelajaran. Yogyakarta: Familia.

Sudjana, Nana dan Ahmad Rivai. (2009). Media Pengajaran. Bandung: Sinar Baru Algesindo.

Tatalovic, M. (2009). Science comics as tools for science education and communication: A brief, exploratory study. Journal of Science and Communication. 8 (4), 1-17.

Tella, A. (2007). The impact of motivation on student's academic achievement and learning outcomes in mathematics among secondary school students in Nigeria. Eurasia J. Math. Sci. \& Technol. Edu. 3(2), 149-156.

Wicaksono, Anggit Grahito dan Jumanto. (2016). Relevansi Pendidikan Karakter dengan Sikap Ilmiah dalam Perspektif Pembelajaran IPA di Sekolah Dasar. Jurnal Eksplorasi UNISRI. 29 (2), 208-216. 